\title{
KESIAPAN DINAS KOMUNIKASI DAN INFORMATIKA DALAM MEWUJUDKAN KLATEN SMART CITY
}

\section{READINESS OF THE COMMUNICATION AND INFORMATION TECHNOLOGY OFFICE IN REALIZING KLATEN SMART CITY}

\section{Rizqy Anita Tamma ${ }^{1}$ \\ Universitas Sebelas Maret, Indonesia $\mathbf{1}$ email: anitatamma@student uns.ac.id}

\section{Is Hadri Utomo ${ }^{2}$} Universitas Sebelas Maret, Indonesia ${ }^{2}$

JGPI

p-ISSN: 2774-907X e-ISSN: 2775-0140 Vol. 1, No. 1, pp. 18-32 April 2021

Unit Publikasi Ilmiah Intelektual Madani Indonesia
Abstrak: Penelitian ini bertujuan untuk menggambarkan kesiapan Dinas Komunikasi dan Informatika dalam mewujudkan Klaten smart city. Metode penelitian ini dilaksanakan secara kualitatif. Informan penelitian dipilih dengan teknik purposive sampling dan snowball sampling. Data diperoleh melalui wawancara terhadap Kepala Bidang Informatika, Kepala Seksi Infrastuktur Jaringan, Penyuluh Teknik Informatika, Pranata Komputer dan beberapa masyarakat Klaten. Kemudian peneliti menggunakan teknik triangulasi untuk menguji keabsahan datanya. Analisis data menggunakan analisis kualitatif dengan tahapan-tahapan yaitu, reduksi data, penyajian data, dan penarikan kesimpulan. Hasil penelitian menunjukkan bahwa Dinas Komunikasi dan Informatika Kabupaten Klaten dikatakan cukup siap dalam mewujudkan Klaten smart city. Hal ini dinilai menggunakan teori e-readiness Mutula dan Brakel yang terdiri dari 5 indikator yaitu enterprise readiness, human resource readiness, information readiness, ICT readiness, dan external environment readiness. Namun masih terdapat beberapa hambatan agar konsep smart city dapat terwujud dengan maksimal, maka dari itu Dinas Komunikasi dan Informatika diharapkan untuk terus meningkatkan kinerjanya agar tujuan dapat tercapai.

Kata Kunci: Kesiapan Organisasi, Smart City, E-Government.

Abstract: This study aims to describe the readiness of the Communication and Informatics Office in realizing Klaten smart city. This research method is carried out qualitatively. The research informants were selected by purposive sampling and snowball sampling techniques. Data was obtained through interviews with the Head of the Informatics, Head of the Network Infrastructure Section, Informatics Engineering Extension, Computer Administration and several Klaten people. Then the researcher used the triangulation technique to test the validity of the data. Data analysis used qualitative analysis with stages, namely, data reduction, data presentation, and drawing conclusions. The results showed that the Office of Communication and Information Technology in Klaten Regency was said to be quite ready to create a Klaten smart city. This is assessed using Mutula and Brakel's e-readiness theory which consists of 5 indicators, namely enterprise readiness, human resource readiness, information readiness, ICT readiness, and external environment readiness. However, there are still some obstacles so that the concept of smart city can be realized optimally, therefore the Communication and Informatics Office is expected to continue to improve its performance so that the goal can be achieved

Keywords: Organizational Readiness, Smart City, E-Government. 


\section{PENDAHULUAN}

Perkembangan teknologi dan informasi merupakan sesuatu yang tidak bisa ditolak kehadirannya. Kondisi tersebut melanda di berbagai belahan dunia, tak terkecuali di Indonesia. Pada saat ini Indonesia memasuki era revolusi industri 4.0 yang ditandai dengan adanya roadmap dan strategi Making Indonesia 4.0 yang dicanangkan oleh Presiden Joko Widodo pada tahun 2018 di acara Indonesia Industrial Summit.

Seiring berjalannya waktu, revolus industri mendisrupsi bidang pemerintahan. Inovasi-inovasi teknologi yang semakin berkembang memaksa pemerintah untuk melakukan perubahan. Hal tersebut karena adanya tuntutan dari masyarakat demi memperoleh pelayanan publik yang efektif, efisien, dan tidak berbelit-belit. Dalam UU No 25 Tahun 2009 tentang Pelayanan publik disebutkan bahwa negara berkewajiban melayani setiap warga negara dan penduduk untuk memenuhi hak dan kebutuhan dasarnya, dalam kerangka pelayanan publik. Maka dari itu perubahan dalam memberikan layanan yang cepat harus segera dilakukan, hal tersebut tidak luput dengan adanya peran teknologi. Salah satu inovasi pemerintah di era digitalisasi yaitu penerapan konsep smart city.

Kementerian Dalam Negeri mendefinisikan smart city merupakan sebuah penataan kota yang terintegrasi dengan cakupan pembangunan yang luas dan dikolaborasikan dengan perkembangan teknologi informasi dan komunikasi yang bertujuan menciptakan perencanaan dan pembangunan kota/kabupaten yang layak huni, maju dan modern, meningkatkan produktivitas daerah dan daya saing ekonomi serta membangun pondasi dasar Indonesia sebagai smart nation (Hasibuan \& Sulaiman, 2019). Pembentukan smart city sendiri bertujuan untuk dapat memberikan solusi atas masalah-masalah yang terjadi disebuah kota/kabupaten. Masalah tersebut antara lain menuntut adanya kemudahan dalam mengurus perizinan, kemudahan pengaduan masyarakat, transparansi pelayanan, meningkatkan kecepatan pelayanan publik, transportasi umum yang dapat diandalakan, peningkatan keamanan, pengelolaan limbah, manajemen sumber daya alam serta data dan informasi.

Konsep smart city pada mulanya diterapkan di negara Amerika Serikat yang dikenalkan oleh sebuah perusahaan teknologi ternama yaitu IBM (International Business Machines Corporation). Namun seiring berjalannya waktu serta mengingat banyaknya manfaat yang dihasilkan dari penerapan smart city, tentu membuat berbagai negara di dunia tertarik untuk mengadopsi serta mengimplementasikannya. Adapun beberapa 
negara yang sudah mengimplementasikan konsep smart city dengan predikat terbaik di dunia yaitu New York, Sans Fransisco, Amsterdam, Tokyo, Melbourne, Perth, Singapura dan lain-lain. Indonesia menjadi salah satu negara yang tertarik untuk mengadopsi konsep smart city untuk memberikan solusi-solusi atas masalah yang ada secara cerdas (smart).

Indonesia merupakan negara yang memiliki jumlah penduduk sebanyak 269 juta jiwa penduduk atau 3,49\% dari total populasi di dunia yang menduduki peringkat keempat negara berpenduduk terbanyak di dunia setelah Tiongkok 1,42 miliar jiwa, India 1,37 miliar jiwa serta Amerika Serikat 328 juta jiwa. Padatnya penduduk di Indonesia menimbulkan berbagai masalah dikarenakan penyebarannya yang tidak merata. Biasanya kota-kota besar di tinggali oleh penduduk yang jumlahnya lebih banyak dari pada di pedesaan. Hal itu disebabkan oleh beberapa faktor antara lain faktor ekonomi dan sosial, kemudahan memperoleh pelayanan publik serta kesenjangan fasilitas baik publik maupun non publik yang dimiliki oleh kota-kota besar dengan daerah-daerah yang tertinggal. Menurut data Badan Pusat Statistik bahwa presentase penduduk daerah perkotaan di Indonesia pada tahun 2020 yaitu mencapai 56,7\% angka tersebut mungkin belum terlalu menunjukkan ketimpangan dengan presentase penduduk di desa. Namun pada tahun 2045, diperkirakan sebanyak 82,37\% penduduk Indonesia akan hidup di perkotaan (Annisah, 2017).

Maka dari itu maraknya penerapan smart city di daerah-daerah di Indonesia diharapkan dapat menyelesaikan permasalahan-permasalahan yang ada antara lain, layanan publik yang kurang memuaskan, sampah, pemukiman kumuh, banjir, kemacetan, angka keamanan yang lemah dan lain sebagainya serta diharapkan dapat menjadikan kehidupan berbangsa dan bernegara yang sejahtera, serta menghilangkan stigma bahwa teknologi tidak hanya dimiliki oleh perkotaan namun daerah-daerah juga dapat menikmatinya.

Kementerian Komunikasi dan Informatika yang berkerja sama dengan Kementerian Pekerjaan Umum dan Perumahan Rakyat (PUPR), Kementerian Dalam Negeri, Badan Perencanaan Pembangunan Nasional (Bappenas), dan Kantor Staf Kepresidenan membentuk Program Gerakan menuju 100 smart city. Dimana program tersebut bertujuan untuk membimbing serta mendampingi Kabupaten/Kota dalam menyusun masterplan smart city agar lebih memaksimalkan pemanfaatan teknologi baik dalam meningkatkan pelayanan masyarakat maupun meningkatkan potensi yang 
dimiliki suatu daerah. Gerakan Menuju 100 Smart City telah bergulir pada tahun 2017 hingga 2019.

Gerakan menuju 100 smart city ini mendorong berbagai daerah untuk berlombalomba dalam mewujudkan konsep kota cerdas. Salah satu daerah yang terpilih menjadi pelengkap gerakan menuju 100 smart city yaitu Kabupaten Klaten. Selanjutnya Bupati Klaten Sri Mulyani menegaskan bahwa penyususnan masterplan Klaten smart city akan dijadikan panduan pembangunan di Klaten yang selaras dengan visi Pemerintah Kabupaten Klaten yaitu mewujudkan Klaten yang maju, mandiri, dan berdaya saing. Maka dari itu tentunya dalam mewujudkan Klaten smart city terdapat beberapa aspek yang perlu disiapkan.

Dinas Komunikasi dan Informatika Kabupaten Klaten sebagai salah satu OPD yang memiliki tugas untuk mendukung Klaten smart city dari sisi teknologi dan informasi. maka dari itu dalam upaya menghindari atau meminimalisir kegagalan dalam menerapkan konsep smart city dibutuhkan kesiapan diri suatu organisasi. Maka dari itu peneliti ingin mengetahui kesiapan Dinas Komunikasi dan Informatika dalam mewujudkan Klaten smart city dengan menggunakan teori e-readiness Mutula dan Brakel yang terdiri dari 5 indikator yaitu enterprise readiness, human resource readiness, information readiness, ICT readiness, dan external environment readiness.

\section{METODE PENELITIAN}

Penelitian ini merupakan jenis penelitian deskriptif kualitatif untuk menggambarkan Kesiapan Dinas Komunikasi dan Informatika dalam mewujudkan Klaten smart city.. Dimana lokasi penelitian berada di Dinas Komunikasi dan Informatika Kabupaten Klaten. Sumber data dalam penelitian ini diperoleh dari hasil wawancara langsung dengan informan. Informan dipilih dengan teknik purposive sampling dan snowball sampling. Yang terdiri dari Kepala Bidang Informatika, Kepala Seksi Infrastuktur Jaringan, Penyuluh Teknik Informatika, Pranata Komputer dan beberapa masyarakat Klaten. Kemudian peneliti menggunakan teknik triangulasi untuk menguji keabsahan datanya. Analisis data menggunakan teknik dari Miles dan Hubermen yang terdiri dari reduksi data, penyajian data, dan penarikan kesimpulan. 


\section{HASIL DAN PEMBAHASAN}

\section{Kesiapan Diskominfo Dalam Mewujudkan Klaten Smart City}

\section{a) Enterprise readiness}

Kesiapan organisasi merupakan faktor yang paling mendasar dalam terwujudnya Klaten smart city, pasalnya tanpa adanya kesiapan dari dalam Dinas Komunikasi dan Informatika Kabupaten Klaten tentu tidak akan terwujudnya faktor-faktor lain yang mendukung kesiapan Kabupaten Klaten sebagai smart city. Dalam mempersiapkan terwujudnya Klaten smart city, hal pertama yang harus dilakukan Dinas Komunikasi dan Informatika Kabupaten Klaten adalah mempersiapkan strategi, nantinya langkahlangkah yang akan ditempuh dalam mewujudkan smart city tersusun secara sistematis dan diharapkan dapat mencapai tujuan yang telah ditentukan. Dalam hal ini strategi kesiapan sudah tertuang pada rencana aksi masterplan smart city Kabupaten Klaten. Didalamnya termuat tujuan, visi misi smart city Klaten, strategi smart city Klaten, rencana aksi smart city Klaten, hingga peta jalan pembangunan smart city Klaten.

Kabupaten Klaten merupakan salah satu kabupaten yang lolos dalam program gerakan menuju 100 smart city. Maka dari itu membuat perencanaan adalah langkah utama yang harus dilakukan. Perencanaan merupakan sebuah proses mendifinisikan tujuan dari suatu organisasi, membuat strategi untuk mencapai tujuan dari organisasi, serta mengembangkan rencana aktivitas kerja organisasi. Dalam hal terwujudnya smart city, Dinas Komunikasi dan Informatika Kabupaten Klaten menyusun masterplan Klaten smart city yang merupakan perencanaan yang menitikberatkan uraian-uraian kebijakan sebuah organisasi dalam hal ini masterplan memiliki tujuan jangka panjang serta ruang lingkup yang sangat luas.

Bupati Klaten Sri Mulyani mengatakan bahwa penyusunan masterplan Klaten smart city sebagai panduan pengembangan dan implementasinya disesuaikan dengan karakter dan potensi yang dimiliki demi mewujudkan Kabupaten Klaten yang cerdas. Dan harapannya dengan pemanfaatan teknologi informasi ini pemerintahan berjalan efektif dan efisien serta pelayanan masyarakat bisa maksimal (Kominfo, 2019). Dalam hal ini Dinas Komunikasi dan Informatika yang berperan sebagai fasilitator dalam mewujudkan Klaten smart city diharapkan mempersiapkan infrastuktur teknologi informasi. Namun kaitannya dengan penyediaan infrastuktur teknologi informasi, tidak hanya fokus untuk Klaten smart city. Ketersediaan infrastuktur teknologi yang memadai 
di Dinas Komunikasi dan Informatika Kabupaten Klaten merupakan suatu nilai tambahan dalam mewujudkan konsep smart city.

Konsep smart city memang tidak selalu mengenai teknologi, namun adakalanya pemanfaatan teknologi menjadi salah satu pendukung terwujudnya smart city. Salah satu pemanfaatan TIK yaitu dibangunnya aplikasi pemerintahan yang diharapkan dapat menjadikan kinerja lebih efektif dan efisien. Dalam hal ini diharpakan bahwa setiap OPD Kabupaten Klaten berkoordinasi dengan Dinas Komunikasi dan Informatika kaitannya pembuatan aplikasi dalam menunjang kinerjanya. Selain menyediakan programmer, nantinya aplikasi-aplikasi tersebut akan di monitoring oleh Dinas Komunikasi dan Informatika apabila ada kendala-kendala.

Adapun upaya Dinas Komunikasi dan Informatika dalam implementasi aplikasi dilakukan secara maksimal, seperti menyediakan sarana prasarana antara lain server, storage, resource, serta dibantu publikasi melalui website klatenkab.go.id, baliho, dan videotron yang ada di Klaten. Selain itu dalam menanggapi tuntutan masyarakat dan tantangan global yang dipicu dengan kemajuan teknologi, salah satu pondasi smart city adalah konektivitas yang diwujudkan dalam konsep Internet of Things (IoT). Dari penjelasan diatas dapat diketahui bahwa secara infrastruktur Dinas Komunikasi dna Informatika sudah siap dalam berpartisipasi di era internet global, hanya saja masih perlunya integrasi anatara sistem-sistem yang sudah terbentuk.

\section{b) Human resource readiness}

Sumber daya manusia merupakan pilar penyangga utama serta sebagai roda penggerak organisasi dalam mencapai visi dan misi serta tujuan yang telah ditetapkan. SDM dalam hal ini pada dasarnya sekelompok manusia yang bekerja pada Dinas Komunikasi dan Informatika Kabupaten Klaten, sehingga tingkat kompetensi dan keahlian dari SDM akan sangat berpengaruh besar pada penerapan konsep smart city. untuk dapat menilai kapasitas dan kualitas yang dimiliki SDM dalam melaksanakan suatu fungsi dapat dilihat dari level of responsibility dan kompetensi SDM tersebut (Azman, 2015).

Ketersediaan SDM di Dinas Komunikasi dan Informatika dirasa masih kurang, hal ini dibuktikan dengan masih adanya beberapa jabatan atau kebutuhan pegawai yang kosong, dari total 36 analisis beban kerja masih terisi 25 SDM. Namun Dinas Kominfo menyiasati kekurangan tersebut dengan merekrut tenaga teknis programmer non PNS dan dengan pertimbangan sesuai dengan kompetensi yang dibutuhkan. Dalam merekrut 
pegawai Dinas Kominfo menggukan pendekatan sosiologis mengingat bersaing dengan perusahaan-perusahaan yang dapat memberikan jaminan lebih baik.

Kaitannya dengan penerapan smart city dan pemanfaatan teknologi, SDM Dinas Kominfo diharapkan memiliki kemampuan untuk memanfaatkan berbagai macam teknologi. Tidak dapat dipungkiri bahwa perkembangan jaman semakin menuntut pemerintah untuk terus meningkatkan pelayanan agar lebih efektif dan efisien. Maka dari itu kesadaran SDM Dinas Kominfo akan pentingnya TIK dalam kegiatan pelayanan publik merupakan suatu keharusan, dikarenakan untuk masuk Dinas Kominfo tentunya melalui seleksi. Meskipun belum 100\% pegawai yang menyadari akan pentingnya manfaat teknologi, namun adanya kesadaran dan kemauan dalam diri untuk belajar tinggi. Dan juga di support dengan adanya pelatihan-pelatihan maupun bimbingan teknis kaitannya meningkatkan kompetensi SDM. Meskipun sempat terhalang oleh adanya pandemi covid 19, namun Dinas Kominfo tetap mengupayakan untuk memberikan peningkatan kompetensi.

Selanjutnya dalam menjalankan tugasnya kaitannya memberikan pelayanan informasi kepada seluruh masyarakat Klaten, SDM Dinas Kominfo dituntut untuk selalu memberikan informasi yang up to date, informatif, dan akurat. Hal ini dibuktikan dengan dikelolanya beberapa media sosial seperti instagram, twitter, youtube serta platform PPID yang selalu memberikan informasi-informasi up to date setiap harinya. Salah satunya program Dinas Kominfo yang mengulas informasi penting dari peristiwa di Kabupaten Klaten yaitu Kuping Panas atau kumpulan informasi penting yang lagi panas yang ditayangkan di channel youtube Dinas Kominfo.

Secara keseluruhan kesiapan SDM Dinas Kominfo memang belum sepenuhnya siap, namun Dinas Kominfo senantiasa mengupayakan beberapa cara untuk terus meningkatkan kualitas dan kompetensi SDM yang dimiliki.

\section{c) Information readiness}

Dalam Peraturan Daerah Kabupaten Klaten Nomor 19 Tahun 2016 tentang Penyelenggaraan Keterbukaan Informasi Publik di Lingkungan Kabupaten Klaten bahwa memberikan pelayanan informasi dan komunikasi bagi publik menjadi salah satu tugas yang harus di wujudkan oleh Dinas Komunikasi dan Informatika. Pada masa sekarang ini informasi publik semakin mudah di dapatkan melalui sosial media yang dimiliki oleh Pemerintah Daerah. Dimana penggunaan teknologi informasi oleh pemerintah untuk memberikan informasi dan pelayanan bagi warganya, urusan bisnis, serta hal-hal lain 
yang berkenaan dengan pemerintah. Selain melalui sosial media baik instagram, twitter, youtube, dan platform lainnya adapun dikembangkan aplikasi pemerintahan yang bertujuan memberbaiki pelayanan pemerintah kepada masyarakat. Namun untuk dapat bekerja secara maksimal, aplikasi pemerintahan harus memuat beberapa komponen seperti jangka waktu penyelesaian, biaya tarif produk, jenis layanan, syarat, ketentuan layanan, poster, slogan, dan lain-lain dengan tujuan informasi yang tersampaikan akan lebih jelas, hal ini sudah terpenuhi pada aplikasi maupun situs website pemerintahan Kabupaten Klaten.

Aplikasi merupakan bentuk perubahan dari dokumen tertulis menjadi sesuatu yang dapat diakses dengan bantuan teknologi, sehingga informasi yang ada di aplikasi harus sesuai dengan apa yang ada di dokumen. Terlebih dalam membuat aplikasi Dinas Kominfo harus berpedoman pada standar teknis dan prosedur pembangunan dan pengembangan aplikasi. Selain itu Pemerintah Kabupaten Klaten juga memiliki situs PPID, yang dimana memuat informasi-informasi lengkap dan akurat yang dapat diakses oleh masyarakat Kabupaten Klaten. Sesuai dengan visi PPID Klaten yaitu menjadikan informasi lebih berarti yang dilengkapi dengan misi mewujudkan pelayanan informasi publik yang benar dan bernilai, mendorong akselerasi pelayanan informasi publik di setiap SKPD di lingkungan Kabupaten Klaten, dan mewujudkan SDM pelayanan informasi yang handal dan profesional. Sehingga dapat dipastikan bahwa ketersediaan informasi pada aplikasi pemerintahan dapat dijamin kelengkapannya. Selain itu tampilan pada aplikasi pelayanan publik di design sedemikian rupa untuk mudah dipahami oleh keberagaman masyarakat Klaten.

Adapun beberapa rekomendasi pengembangan aplikasi pada masterplan Klaten smart city diharapkan dapat menjadikan interaksi pemerintah dengan masyarakat lebih baik dan aktif. Tentunya aplikasi-aplikasi pemerintahan baik yang sudah di bangun maupun akan dibangun merupakan bentuk koordinasi Dinas Kominfo dengan berbagai OPD. Meskipun perencanaan pembangunan aplikasi ditargetkan selesai pada 2021, namun sudah terdapat beberapa aplikasi yang berjalan sesuai fungsinya. Beberapa aplikasi tersebut adalah aplikasi yang berlatar belakang melayani masyarakat seperti Sipon Keduten dan Matur Dokter, sementara yang lain masih dalam tahap pembangunan dan uji coba.

Namun mengingat bahwa sesuatu yang diciptakan oleh manusia tidak terlepas dari ketidaksempurnaan. Maka dari itu masih terdapat beberapa hambatan pada aplikasi 
maupun website Pemerintah Kabupaten Klaten baik dari sisi pengguna maupun penyedia layanan. Seperti kondisi aplikasi yang down sehingga tidak dapat diakses yang dipengaruhi oleh kondisi jaringan. Namun kondisi tersebut selalu dalam pantauan Dinas Kominfo, sehingga langsung di ambil tindakan untuk diperbaiki.

Selain kondisi aplikasi yang selalu dimonitoring, kemanan data dan informasi tidak kalah penting untuk dilakukan monitoring 24 jam nonstop. Internet merupakan media informasi dan data yang sangat terbuka, namun dengan kecanggihan kemajuan teknologi berdampak pada keamanan internet yang sangat rentan terhadap serangan sistem informasi. Dalam penyelenggaraan tata kelola TIK sebagai bentuk mewujudkan Klaten smart city, faktor kemanan informasi sangat penting untuk diperhatikan. Hal ini juga diatur dalam Peraturan Bupati Nomor 18 Tahun 2018 tentang Penyelenggaraan $e$ Goverment bahwa pemerintah daerah wajib mengelola data dalam sistem informasi untuk kepentingan internal dan eksternal dengan memperhatikan keamanan informasi.

\section{d) ICT readiness}

Kesiapan teknologi informasi dan komunikasi dipandang sebagai sektor produksi dan strategi e-readiness nasional. Peran TIK dalam konsep smart city yaitu mempercepat proses layanan masyarakat, dengan pengembangan aplikasi sistem informasi dalam rangka mewujudkan dan meningkatkan penyebarluasan informasi dan pemberdayaan kepada masyarakat. Hal ini dapat dilihat dari bagaimana Dinas Kominfo memanfaatkan TIK dalam menunjang kegiatan pelayanan publik yang ada di unit pelayanan informasi. Diketahui bahwa sudah tersebar 57 peralatan komputer di seluruh OPD Kabupaten Klaten ketersediaan peralatan komputer di setiap OPD tentunya sangat menunjang kinerja baik dalam aktivitas sehari-hari maupun kaitannya dengan memberikan pelayanan publik berbasis elektronik.

Dalam memberikan pelayanan informasi secara online tentunya sudah menjadi tugas Dinas Kominfo untuk memenuhi jaringan internet untuk setiap OPD, hal ini dibuktikan dengan disediakannya jaringan LAN serta bandwith yang telah tersebar di berbagai OPD. Dengan adanya LAN serta bandwith tentunya dapat memberikan kualitas jaringan yang lebih baik. Terlebih pada OPD yang memiliki prioritas untuk memenuhi pelayanan kepada masyarakat, tentunya kemudahan serta kualitas jaringan yang baik sangat dibutuhkan. Sejauh ini kualitas jaringan yang didistribusikan cukup bagus, hal ini dibuktikan dengan minimnya komplain yang diterima oleh Dinas Kominfo terkait buruknya kualitas jaringan. Adapun dalam memberikan pelayanan kepada masyarakat 
terkait kemudahan dalam mengakses internet, Dinas Kominfo memberikan layanan hotspot gratis di berbagai titik ruang publik. Sejauh ini sudah terdapat 20 titik hotspot gratis, dengan kecepatan berkisar 20 mbps. Hal tersebut merupakan sebuah upaya dalam mendukung program gerakan menuju 100 smart city.

Selanjutnya pada Seksi Persandian dan Telekomunikasi Dinas Komunikasi dan Informatika Kabupaten Klaten, salah satu tugasnya yaitu melaksanakan pemulihan data atau sistem jika terjadi gangguan operasional persandian dan keamanan informasi. Pentingnya informasi yang dimiliki Dinas Kominfo membuat keamanan informasi tak kalah penting untuk diperhatikan. Dalam penggunaan aplikasi pelayanan publik tentunya masyarakat diberikan jaminan mengenai keamanan data-data yang telah di upload sehingga tidak khawatir akan terjadinya kebocoran data. Berbicara mengenai sistem online tentunya tidak ada di dunia ini yang benar-benar secure, maka dari itu Dinas Kominfo mengupayakan keamanan data dan informasi dalam mengakses aplikasi pelayanan publik salah satunya dengan sistem firewall yang di monitoring 24 jam. Firewall merupakan sebuah sistem proteksi untuk melaksanakan pengawasan lalu lintas paket data yang menuju atau meninggalkan sebuah jaringan komputer sehingga paket data yang telah diperiksa dapat diterima maupun ditolak atau bahkan di modifikasi terlebih dahulu sebelum memasuki dan meninggalkan jaringan. Selain menggunakan sistem firewall, Dinas Kominfo juga mengupayakan untuk aplikasi yang melalui website menggunakan domain https. Menggunakan domain https (hypertext transfer protocol secure) akan lebih meminimalisir tejadinya kebocoran data-data atau informasi yang diakses. Meskipun belum semua aplikasi yang melalui website di Pemerintah Kabupaten Klaten menggunakan domain https, namun Dinas Kominfo terus mengupayakan agar aplikasi serta website pemerintahan dapat lebih secure.

Kaitannya dengan aplikasi yang berorientasi dalam memberikan pelayanan publik selain untuk mewujudkan konsep smart city dalam dimensi e-goverment, pemanfaatan teknologi informasi tentunya memiliki tujuan agar dapat memaksimalkan pelayanan masyarakat dengan lebih responsif, efektif, efisien, dan akuntabel. Hal ini sudah dirasakan manfaatnya oleh masyarakat Klaten. Memenuhi pelayanan menggunakan aplikasi selain menghemat biaya dan waktu, pada keadaan pandemi covid 19 ini masyarakat tidak khawatir untuk berinteraksi dengan orang lain. 


\section{e) External environment readiness}

Kesiapan lingkungan eksternal Dinas Kominfo dapat dijadikan dukungan dalam mewujudkan Klaten smart city. Salah satunya yaitu dengan adanya kebijakan atau peraturan daerah yang mengatur mengenai smart city di Kabupaten Klaten. Adanya kebijakan dirasa penting untuk memperjelas akan ke arah mana langkah yang akan dijalankan. Dikarenakan terdapat beberapa daerah yang mengalami keraguan dalam mewujudkan smart city dikarenakan tidak adanya arah yang jelas. Namun hal yang sama terjadi pada Kabupaten Klaten, diketahui bahwa Klaten lolos dalam program gerakan menuju 100 smart city pada tahun 2019. Sehingga pada saat ini Kabupaten Klaten masih mengacu pada roadmap smart city dalam pembangunan smart city. Namun draft rancangan perbup mengenai rencana induk smart city sudah ada, harapannya agar segera di sahkan agar dapat dijadikan referensi penyusunan smart city.

Selain itu dukungan pemerintah juga menjadi garda terdepan dalam mewujudkan smart city. Salah satu bentuk dukungannya yaitu dibentuknya Dewan smart city yang bertugas mengarahkan, memantau, dan mengendalikan perkembangan smart city dan melaporkan secara berkala kepada Bupati. Dan juga membentuk tim pelaksana teknis yang bertugas menyusun rencana induk pengembangan smart city, menyusun draf evaluasi, menganalisa dan merekomendasi pencapaian kinerja, mendorong dan mengarahkan perangkat daerah serta membuat langkah inovatif dan kreatif untuk pengembangan smart city. Dukungan lain juga diberikan dalam bentuk pelatihanpelatihan ke pemerintah kaitannya dalam memberi edukasi mengenai smart city.

Namun dengan adanya pandemi covid 19 ini, banyak agenda yang telah disusun oleh Dinas Kominfo seperti pengadaan pelatihan maupun sosialisasi menjadi terhambat. Meskipun beberapa agenda dirubah menjadi pertemuan online namun hal tersebut dirasa belum berjalan maksimal. Situasi ini juga berdampak pada masyarakat, dimana masih belum meratanya pengetahuan dalam penggunaan teknolgi serta mengetahui lebih jelas mengenai konsep smart city.

\section{Hambatan dan Upaya Diskominfo Dalam Mewujudkan Klaten Smart City}

Dalam mewujudkan Klaten smart city, Dinas Komunikasi dan Informatika Kabupaten Klaten berbagai hambatan antara lain

a) Belum adanya regulasi yang mengatur mengenai smart city. Inisiasi dan penerapan smart city di Indonesia belum memiliki landasan hukum. Padahal sebuah regulasi merupakan suatu hal penting dalam penerapan suatu kebijakan yang akan di 
implementasikan yang dijadikan acuan. Dengan tidak adanya regulasi yang mengatur tentang smart city mengakibatkan konsep dasar mengenai kota cerdas belum sepenuhnya dipahami baik oleh pemerintah pusat maupun daerah. Hal serupa juga dialami oleh Pemerintah Kabupaten Klaten yang masih berpedoman pada masterplan smart city dalam mewujudkan Klaten Kota Cerdas.

b) Kurangnya Sumber Daya Manusia. Untuk dapat mewujudkan konsep smart city tentunya dibutuhkan kerjasama dari beberapa SDM dalam Dinas Komunikasi dan Informatika Kabupaten Klaten. Dimana setiap pegawai memiliki job desk yang berbeda-beda. Namun dalam kebutuhan PNS di Dinas Komunikasi dan Informatika masih terdapat beberapa jabatan yang kosong. Maka dari itu masih dibutuhkan SDM yang berkompetensi dan berkualitas dalam bidangnya.

c) Keterbatasan anggaran. Untuk mewujudkan konsep smart city pemerintah Kabupaten Klaten tentu harus mengeluarkan investasi yang cukup besar. Kaitannya dengan teknologi, tentunya membutuhkan anggaran yang tidak sedikit apalagi jika ingin berkualitas. Namun karena adanya pandemi covid 19 ini, berefek pada pengurangan anggaran mewujudkan smart city.

d) Kurangnyga Koordinasi dengan OPD lain. Dalam mewujudkan Klaten smart city, kaitannya dengan pembuatan aplikasi pelayanan publik. Dinas Komunikasi dan Informatika yang bertugas menyediakan server dan tenaga programmer aplikasi. Mengharapkan bahwa setiap OPD berkordinasi dnegan Diskominfo dalam memanfaatkan sarana prasarana TIK Pemerintah Kabupaten Klaten, serta mengenai pengembangan sistem. Karena masih terdapat beberapa OPD yang menggunakan penyedia jasa dalam proses pembangunan aplikasi.

e) Masyarakat belum siap. Masyarakat merupakan suatu kompenen penting dalam pembangunan daerah. Dalam mewujudkan Klaten smart city, peran masyarakat dirasa sangat dibithkan baik menjadi pelaku dalam membangun kota cerdas, menjaga baik sarana dan prasarana publik, terutama kaitannya dengan pengaplikasian pelayanan publik berbasis teknologi. Integrasi aplikasi menjadi faktor penting dalam pelaksanaan berbagai program pemerintah yang berujjung pada pembangunan smart city dengan tujuan memperpendek alur layanan publik yang dinilai panjang dan berbelit-belit. Namun hal ini akan menjadi sia-sia apabila masih banyak masyarakat yang belum paham bagaimana cara mengaksesnya. 
f) Adanya pandemi Covid 19. Kasus virus covid 19 ini memang tidak hanya menggemparkan negara Indonesia saja, namun hampir seluruh bagian dunia merasakannya. Namun virus ini memiliki dampak yang begitu besar dalam aspek kehidupan, tak terkecuali untuk Dinas Komunikasi dan Informatika dalam mewujudkan Klaten smart city. Beberapa rencana yang sudah ditetapkan menjadi terhambat karena larangan untuk mengumpulkan massa dalam jumblah banyak, seperti pelatihan-pelatihan teknis guna meningkatkan kualitas SDM Dinas Komunikasi dan Informatika maupun pelaksanaan sosialisasi kepada masyarakat dalam rangka memberikan pengetahuan mengenai konsep smart city. selain itu adanya pandemi berpengaruh terhadap pengurangan anggaran guna menangani virus tersebut agar tidak semakin banyak menelan korban.

Sedangkan upaya yang dilakukan Dinas Komunikasi dan Informatika Kabupaten Klaten dalam mewujudkan Klaten smart city adalah sebagai berikut :

a) Kaitannya dengan belum adanya regulasi yang mengatur tentang Klaten smart city. Dinas Komunikasi dan Informatika Klaten mengacu pada roadmap smart city yang langkah selanjutnya menjadikannya rancangan draft peraturan bupati dan harapannya agar segera ditetapkan sebelum pergantian Bupati.

b) Terbatasnya anggaran tidak menjadi masalah apabila Dinas Komunikasi dan Informatika dapat mengelola dengan baik.

c) Demi memenuhi kebutuhan Sumber Daya Manusia di Dinas Komunikasi dan Informatika Kabupaten Klaten, diadakan rekruitmen pegawai non NS dengan pendekatan sosiologis dan mempertimbangkan kualitas dan kompetensi yang dimiliki.

d) Meningkatkan sosialisasi kepada masyarakat mengenai konsep smart city dan pentingnya dukungan masyarakat dalam mewujudkan Klaten smart city.

e) Meningkatkan kerjasama dan koordinasi dengan OPD lain dalam memanfaatkan sarana prasana TIK Pemerintah Kabupaten Klaten dengan memberikan surat edaran.

f) Menggencarkan masyarakat untuk senantiasa menggunakan aplikasi pelayanan publik dalam memenuhi kebutuhannya terutama dalam masa pandemi. 


\section{KESIMPULAN}

Dari hasil penelitian mengenai kesiapan Dinas Komunikasi dan Infromatika dalam mewujudkan Klaten smart city dengan 5 indikator enterprise readiness, human resource readiness, information readiness, ICT readiness, dan external environment readiness dapat dikatakan bahwa Dinas Komunikasi dan Informatika Kabupaten Klaten sudah cukup siap. Hanya saja masih terdapat beberapa hambatan, antara lain belum adanya regulasi yang mengatur tentang smart city, masih kurangnya SDM, keterbatasan anggaran, kurangnya koordinasi denga OPD lain, belum meratanya masyarakat yang melek teknologi, serta adanya pandemi Covid 19 ini yang mengakibatkan beberapa agenda yang sudah tersusun menjadi terhambat. Oleh karena itu, direkomendasikan kepada Dinas Komunikasi dan Informatika dalam mewujudkan Klaten smart city yaitu melakukan pengelolaan anggaran sebaik mungkin, menggiatkan pelatihan-pelathian maupun bimbingan teknis sebagai upaya meningkatkan kualitas SDM, serta meningkatkan sosialisasi kepada masyarakat mengenai konsep smart city akan pentingnya dukungan masyarakat dalam mewujudkan Klaten smart city.

\section{REFERENSI}

Annisah. (2017). Usulan Perencanaan Smart City: Smart Governance Pemerintah Daerah Kabupaten Mukomuko. Jurnal Masyarakat Telematika dan Informasi, 8(1), 59-80.

Azman, T. (2015). Analisis Komitmen Organisasi, Kesiapan Sumber Daya Manusia, Infrastuktur Serta Sistem Informasi Dalam Menerapkan Standar Akuntansi Pemerintah Berbasis Akrual. Jurnal Sorot, 10(1), 131-142.

Bitjoli, B. E., Rindengan, Y. D., \& Karouw, S. D. (2017). Analisa Kesiapan Kota Cerdas (Studi Kasus: Pemerintah Kota Manado). E-Journal Teknik Informatika, 12(1).

Eniyati, S., NS, R. C., Retnowati, Mulyani, S., \& A.P, K. M. (2017). Perhitungan Tiingkat Kesiapan Implementasi Smart City Dalam Perspektif SMart Governance dengan Metode Fis Mamdani. Jurnal Dinamik, 22(1), 39-48.

Hasibuan, A., \& Sulaiman, O. K. (2019). Smart City, Konsep Kota Cerdas Sebagai Alternatif Penyelesaian Masalah Perkotaan Kabupaten/Kota di Kota-Kota Besar Provinsi Sumatera Utara. Buletin Utama Teknik, 14(2), 127-135.

Insani, P. A. (2017). Mewujudkan Kota Responsif Melalui Smart City. PUBLISIA Jurnal Ilmu Administrasi Publik, 2(1), 25-31.

Kominfo. (2019, Oktober 14). Dipetik September 04, 2020, dari klatenkab.go,id: https://klatenkab.go.id/implementasi-klaten-smartcity-jangantinggalkanekonomi-umkm-2/. 
Pertiwi, W. K. (2019, Oktober 04). Singapura Teratas di Ranking Smart City Dunia, Jakarta Nomor Berapa? Dipetik April 07, 2020, dari Kompas.com: https://tekno.kompas.com/read/2019/10/04/19070047/singapura-teratasdiranking-smart-city-dunia-jakarta-nomor-berapa.

Pratama, I. P. (2014). Smart City beserta Cloud Computing dan Teknologi-Teknologi Pendukung Lainnya. Bandung: Informatika.

Yusrizal. (2014). Kesiapan Instansi Dalam Pembentukan Unit Pelayanan Informasi di Pemerintah Kabupaten Asahan. Jurnal Penelitian Komunikasi dan Pembangunan, 15(1), 73-88. 